\title{
“Tia, é pra ler ou só pra olhar as figuras?": uma análise sobre gêneros multimodais a partir de livros didáticos dos anos iniciais
}

\author{
Alessandra Costa ${ }^{\mathrm{i}}$ \\ Cristiane Freitas da Silva ${ }^{\text {ii }}$
}

\section{RESUMO}

Este artigo objetiva analisar o trabalho com os gêneros discursivos multimodais nos anos iniciais de escolarização, a partir do uso do livro didático de Língua Portuguesa em sala de aula, visando compreender as propostas que este material apresenta em relação aos gêneros enquanto objeto de ensino e de aprendizagem da linguagem. $O$ percurso metodológico que organiza os dados e constitui as análises está assentado, prioritariamente, na pesquisa documental, tendo uma perspectiva de abordagem quantitativa e qualitativa direcionada à estruturação e leitura dos dados extraídos dos 5 volumes da coleção Ápis da Editora Ática, referentes aos anos iniciais do Ensino Fundamental. Tais documentos foram enviados às escolas pelo Programa Nacional do Livro Didático (PNLD) e utilizados nos anos letivos de 2019 a 2022.

Palavras-chave: Gêneros Multimodais; Livro Didático; Leitura.

\begin{abstract}
This article aims to analyze the work with multimodal discursive genres in the early years of schooling, from the use of the Portuguese Language Textbook in the classroom, in order to understand proposals that this material presents concerning genres as a teaching and language learning object. The methodological approach that organizes the data and constitutes the analysis is based primarily on documentary research, within a quantitative and qualitative approach perspective aimed at structuring and reading the data extracted from the five volumes of Ápis collection from the Ática publishing company for the early years of Elementary School. Such documents were sent to schools by the Brazilian National Textbook Program (PNLD, in Portuguese) and used in the school years from 2019 to 2022.
\end{abstract}

\footnotetext{
${ }^{i}$ Mestranda em Educação pela Universidade Federal de Mato Grosso (UFMT), campus de Rondonópolis, e membro do grupo de pesquisa Alfabetização e Letramento Escolar (ALFALE). É professora efetiva de Língua Portuguesa na rede estadual de ensino de Mato Grosso (SEDUC/MT).

ORCID: https://orcid.org/0000-0001-5287-1519 | prof.alessandrapiovezan@ gmail.com

ii Mestra em Educação pela Universidade Federal de Mato Grosso (UFMT) na linha de Linguagens, Cultura e Construção do Conhecimento: Perspectivas Histórias e Contemporânea, e membro do grupo de pesquisa Alfabetização e Letramento Escolar (ALFALE). É professora efetiva da rede estadual de ensino do Mato Grosso, nos anos iniciais da Educação Básica e diretora escolar. ORCID: https://orcid.org/0000-0002-3430-5238 |cris_educ_roo@hotmail.com
} 
Keywords: Multimodal Genres; Textbook; Reading.

\title{
INTRODUÇÃO
}

O avanço tecnológico das mídias digitais tem transformado as nossas práticas linguísticas através de modos de leitura e escrita contemporâneos. Por conseguinte, os usos da linguagem têm se modificado para que tantas demandas sociais e comunicativas sejam atendidas. Essas mudanças revelaram e enfatizaram outro tipo de texto: o texto multimodal. De acordo com os estudos da Semiótica Social ${ }^{1}$, o texto multimodal é "aquele cujo significado realiza-se por mais de um código semiótico" (KRESS E VAN LEEUWEN², 1996, p. 183 op. cit MAROUN, 2006, p. 44).

Rojo e Barbosa (2015) endossam tal concepção, afirmando que

\begin{abstract}
[1]íngua oral e escrita (modalidade verbal), linguagem corporal (gestualidade, danças, performances, vestimentas - modalidade gestual), áudio (música e outros sons não verbais - modalidade sonora) e imagens estáticas e em movimento (fotos, ilustrações, grafismos, vídeo, animações - modalidades visuais) compõem hoje os textos da contemporaneidade, tanto em veículos impressos como, principalmente, nas mídias analógicas e digitais. (ROJO e BARBOSA, 2015, p. 108).
\end{abstract}

O uso desses textos em sala de aula permite o acesso a diferentes saberes, a novas habilidades de leitura e escrita e a novos conhecimentos exigidos na sociedade atual, ou seja, possibilita novos letramentos. Os autores ainda mencionam que o desenvolvimento da competência leitora, tanto dos textos verbais como dos multimodais, é um requisito para que o indivíduo se possa inserir nas diversas práticas sociais que demandam leitura e escrita de forma crítica, democrática e cidadã.

A perspectiva da multimodalidade possibilitou a constituição de um conjunto de textos híbridos de gêneros diversos: os gêneros multimodais, que além de se fazerem presentes nas plataformas digitais adentraram também aos materiais impressos e, entre eles, o livro didático, tal como podemos notar no edital de convocação para o processo de inscrição e avaliação de obras didáticas para o Programa Nacional do Livro e do Material Didático (PNLD) do ano de 2019. Publicado pelo Ministério da Educação (MEC), o PNLD aponta como critério de seleção que a obra contemple em seu conteúdo o ensino 
dos gêneros multimodais, destacando a necessidade da relação com múltiplas linguagens, bem como o desenvolvimento da oralidade, da percepção, da compreensão e da representação, estas que se constituem bases essenciais para o processo de multiletramento.

Os pressupostos teóricos deste trabalho baseiam-se na teoria dos gêneros discursivos bem como no Interacionismo Sociodiscursivo (ISD), pois compreendemos que o desenvolvimento do sujeito ocorre mediante a interação social através da linguagem que se materializa discursivamente pelos gêneros textuais, e também em alguns princípios da Semiótica Social, no intuito de compreender o fenômeno da multimodalidade.

Para a realização deste estudo, procedeu-se com uma análise documental, respaldada na abordagem quantitativa e qualitativa, considerando o que preceitua Gatti (2006) de que

[...] é preciso considerar que os conceitos de quantidade e qualidade não são totalmente dissociados e opostos. Epistemologicamente, quantidade é uma interpretação, uma tradução, um significado que é atribuído à grandeza com que um fenômeno se manifesta (portanto é uma mensuração dessa grandeza sob certos critérios), e ela precisa ser interpretada qualitativamente pois, em si, seu significado é restrito. (GATTI, 2006, p. 3)

O material investigado nesta pesquisa corresponde a cinco volumes de Língua Portuguesa da coleção Ápis da Editora Ática, referentes aos anos iniciais do Ensino Fundamental, escrito pelas autoras Ana Trinconi, Terezinha Bertin e Vera Marchesi, escolhidos pela maioria das escolas da rede estadual de ensino, em Rondonópolis/MT, para os anos letivos de 2019 a 2022, através do Programa Nacional do Livro Didático (PNLD).

A opção pela análise de toda essa coleção apoia-se na intenção de observar como a proposta de encaminhamento didático dos manuais em relação aos gêneros multimodais ao longo dos cinco primeiros anos da Educação Básica acontece de forma progressiva e continuada, visando o desenvolvimento do aluno e o aprimoramento de suas aprendizagens, mesmo que este estudo represente apenas um ensaio e um intento de discussão, haja vista a sua extensão para tal.

Assim, destacamos que foi feito um levantamento da quantidade de gêneros multimodais que o material apresenta e suas respectivas identificações e recorrências, seguido da verificação da função que tais gêneros ocupam, apresentando os dados através 
de tabelas e os contextualizando, como é pertinente nessa abordagem. A investigação, enfocando os anos iniciais, pauta-se no entendimento de que, quanto antes o aluno tiver contato com a maior variedade de gêneros textuais, mais completo será seu processo de multiletramentos.

Destarte, objetiva-se analisar o trabalho realizado com os gêneros multimodais, a partir do uso do livro didático em sala de aula, verificando a efetividade da presença desses novos gêneros, como eles estão inseridos, que tratamento lhes é dado, bem como as atividades propostas com estes textos nesse material, que muitas vezes é um dos primeiros acessos à leitura que o aluno da rede pública vivencia, além de ser um potencial instrumento de apoio no processo ensino - aprendizagem nos anos iniciais de escolarização.

\section{ALGUMAS CONCEPÇÕES SOBRE GÊNEROS TEXTUAIS}

Compreendemos que o homem se constitui sujeito pela linguagem e que esta tem o dialogismo como pilar fundamental. Logo, podemos inferir que toda linguagem é dialógica, o que significa dizer que todo enunciado é sempre de um locutor para seu interlocutor. De igual modo, a constituição da linguagem e a possibilidade de criação de sentido dos textos, sejam eles orais ou escritos, acontece através da interação dos sujeitos entre si e com o próprio texto. Bakhtin (2008) elucida-nos que

\footnotetext{
[a] palavra, a palavra viva, indissociável do convívio dialógico, por sua própria natureza quer ser ouvida e respondida. Por sua natureza dialógica, ela pressupõe também a última instância dialógica. [...] Minha palavra permanece no diálogo contínuo, no qual ela será ouvida, respondida e reapreciada. (BAKHTIN, 2008, p. 337)
}

Os gêneros do discurso organizam-se em torno de enunciados construídos conforme os objetivos de cada uma dessas esferas e se constituem a partir de três elementos: o conteúdo temático, o estilo e a construção composicional. De acordo com a teoria bakhtiniana, eles estão divididos em primários e secundários, sendo estes os enunciados simples, imediatos, espontâneos, do uso cotidiano, e aqueles elaborados em contexto cultural mais formal, mais complexo e, em geral, através da escrita.

Bronckart (1999) instrui que 
[a] escolha do gênero deverá, portanto, levar em conta os objetivos visados, o lugar social e os papéis dos participantes. Além disso, o agente deverá adaptar o modelo do gênero a seus valores particulares, adotando um estilo próprio, ou mesmo contribuindo para a constante transformação dos modelos. (BRONCKART, 1999, p. 150)

Em uma interação, para que as ações de linguagem se efetivem é preciso a seleção de um gênero discursivo, visto que os gêneros funcionam enquanto regulação e um produto das atividades sociais de linguagem. Assim, a palavra está em constante renovação pelo discurso que se concretiza por meio do diálogo e se ressignifica em um processo contínuo de inacabamento, ou seja, o discurso é sempre novo e nunca se repete, ainda que seja pronunciado pelo mesmo sujeito (ao repeti-lo, automaticamente, o modifica).

Sobre isso, Bazerman (2012) enfatiza que

[...] los géneros son siempre rehechos por cada nueva acción individual y que los espacios discursivos dentro de los géneros reconocidos crean espacios de oportunidad para la expresión individual dentro de las relaciones y actividades socialmente ordenadas. (BAZERMAN, 2012, p. 33)

Neste sentido, Marcuschi (2008) adverte que não se pode configurar "os gêneros como modelos estanques nem como estruturas rígidas, mas como formas culturais e cognitivas de ação social corporificadas de modo particular na linguagem", assim como devemos entender que, apesar de não surgirem a cada interação entre falantes, eles são transmitidos social e historicamente, sendo o resultado dessa cooperação em sua manutenção ou alteração. O pesquisador reitera também que "assim como a língua varia, também os gêneros variam, adaptam-se, renovam-se e multiplicam-se" (MARCUSCHI, 2008, p. 19).

Bazerman (2012) esclarece que os gêneros são

[...] como una serie de categorías siempre cambiantes y culturalmente destacadas que moldean los sitios de actividad literaria en cualquier tiempo y espacio. Los géneros son lo que las personas reconocen como tales en cualquier punto en el tiempo; y pueden reconocerlos por su nombramiento explícito, institucionalización y regularización, a través de varias formas de sanción o recompensa social. O bien, las personas pueden reconocer el género a través de la organización implícita de prácticas dentro de formas ejemplares de interacción escrita. (BAZERMAN, 2012, p. 12) 
Os gêneros fundamentam-se enquanto práticas sociais da linguagem que necessitam ser reconhecidas e apreendidas, a fim de serem utilizadas nos momentos de interação. Por este prisma, pode-se compreender que "a apropriação dos gêneros é um mecanismo fundamental de socialização, de inserção prática nas atividades comunicativas humanas" (BRONCKART, 1999, p. 103).

Dolz e Schneuwly (2011, p. 74) ressaltam que "é através dos gêneros que as práticas de linguagem materializam-se nas atividades dos aprendizes" e que a escola sempre trabalhou com eles, uma vez que esta, enquanto esfera de atividade humana, possui uma linguagem própria. Salientam, também, que “o gênero pode, assim, ser considerado um mega-instrumento que fornece um suporte para a atividade nas situações de comunicação e uma referência para os aprendizes" (DOLZ E SCHNEUWLY, 2011, p. 64-65, grifos nossos).

Logo, é fundamental que a escola priorize o trabalho com os gêneros textuais, desde seu conhecimento até sua produção, ou seja, por meio das sequências didáticas, valorizando todos os conhecimentos linguísticos e discursivos que os alunos já possuem, construídos através de interações sociais vivenciadas no contexto cultural em que estão inseridos.

\section{OS GÊNEROS MULTIMODAIS NOS ANOS INICIAIS}

Embora sejam processos distintos, para que a aprendizagem dessas habilidades se efetive de forma profícua, elas necessitam ser trabalhadas ao mesmo tempo, de forma equilibrada, visto que são indissociáveis. Logo, apenas alfabetizar não basta, é fundamental alfabetizar letrando.

Estudos evidenciam que leitura e escrita estão diretamente ligadas a inúmeros usos sociais que realizamos a partir dessas práticas, constituindo diversos tipos de letramentos, ou multiletramentos, pois estão vinculados à multiplicidade cultural, linguística, midiática e semiótica.

Importante ressaltar que os letramentos estão para além do mero ler e escrever, muito menos se restringem à esfera do ensino no espaço escolar - são fenômenos sociais de linguagem. Porém, devido ser a escola um lócus propício e natural de interação social, 
Pode-se afirmar que a escola, a mais importante das agências de letramento, preocupa-se, não com o letramento, prática social, mas com apenas um tipo de prática de letramento, a alfabetização, o processo de aquisição de códigos (alfabético, numérico), processo geralmente percebido em termos de uma competência individual necessária para o sucesso e promoção na escola. Já outras agências de letramento, como a família, a igreja, a rua como lugar de trabalho, mostram orientações de letramento muito diferentes (KLEIMAN, 1995 , p. 20)

As transformações nos meios de comunicação e a veiculação da informação, bem como a ampliação do acesso às mídias digitais trouxeram muitas mudanças ao ato de leitura. Isso "porque hoje dispomos de novas tecnologias e ferramentas de 'leitura-escrita' que, convocando novos letramentos, configuram os enunciados/textos em sua multissemiose ou multimodalidade" (ROJO, 2010, p. 19).

A multimodalidade textual é determinada pela combinação entre diferentes modos de expressão na busca da criação de sentido da leitura, e abrange um conjunto de duas ou mais modalidades de comunicação, seja ela a fala, o gesto, o texto ou a imagem. Esses novos enunciados/textos, denominados multimodais ou multissemióticos, caracterizamse pela utilização de múltiplos modos de representação da língua conectados na estruturação textual, visando à construção de significados, inclusive "o que faz com que um modo seja multimodal são as combinações com outros modos para criar sentidos" (DIONÍSIO, 2014, p. 42).

Rojo (2010) explicita que "a multimodalidade não é apenas a soma de linguagens, mas a interação entre linguagens diferentes em um mesmo texto", ela se dá através da articulação entre palavras e imagens e, assim, origina novos gêneros discursivos, que obviamente "também permitem observar a maior integração entre os vários tipos de semioses: signos verbais, sons, imagens e formas em movimento" (MARCUSCHI, 2008, p. 21), possibilitando a interação com leitores e se materializam nos materiais impressos e nos digitais.

Marcuschi (2008) adverte que

[e]sses gêneros que emergiram no último século no contexto das mais diversas mídias criam formas comunicativas próprias com um certo hibridismo que desafia as relações entre oralidade e escrita e inviabiliza de forma definitiva a velha visão dicotômica ainda presente em muitos manuais de ensino de língua. (MARCUSCHI, 2008, p. 21) 
Dentro desta perspectiva, as outras semioses deixam de ter apenas um aspecto estético, ilustrativo, transcendendo o foco exclusivo na linguagem verbal escrita, que acaba por perder sua "pseudo-supremacia" em relação às demais modalidades de linguagem, visto que ela deixa de ser a única a transmitir as informações e efetivar as comunicações. Nesse sentido, Rojo (2010) assegura que

[...] já não basta mais a leitura do texto verbal escrito - é preciso colocá-lo em relação com um conjunto de signos de outras modalidades de linguagem (imagem estática, imagem em movimento, som, fala) que o cercam, ou intercalam ou impregnam. (ROJO, 2010, p. 7)

Paes de Barros (2009) esclarece que na língua há diferentes modos de representação na composição textual, e a escrita é apenas um destes. Portanto, na busca da produção de significado, o texto multimodal articula elementos verbais e não verbais, em uma relação quase imanente.

Não é possível ler apenas a mensagem escrita, pelo fato de o texto verbal constituir um elemento representacional que coexiste com uma série de outros, como a formatação, o tipo de fonte, a presença de imagens e todo tipo de informação advinda de quaisquer modos semióticos embutidos na cultura humana e que estão presentes no texto. (DELL'ISOLA, 2007, p. 1699)

Em função disso, é preciso compreender que, no processo de leitura, o foco está em todas as representações que compõem o texto e não apenas em um destes elementos, pois "inevitavelmente, durante a leitura de um texto verbal ou pictorial, o leitor recorre a outros textos, fazendo referência, por exemplo, ao seu conteúdo, ao seu estilo, a sua forma estrutural, com os mais variados propósitos discursivos". (DELL'ISOLA, 2007, p. 1700).

Isto posto, é salutar acrescentar que

[e]sses gêneros, como vários outros, extrapolaram os ambientes digitais e adentraram nos impressos (por exemplo, no Livro Didático) e, por sua vez, convocam novos letramentos, na medida em que orquestram em sua composição imagens e outras semioses, implicando múltiplas formas de significar. (PAES DE BARROS; COSTA, 2012, p. 39)

A formação de alunos multiletrados demanda que estes estejam aptos a ler, compreender, analisar, interpretar, produzir e interagir com gêneros textuais de diferentes esferas sociais. Nesse sentido, a presença de textos multimodais no livro didático é de 
extrema relevância na construção do conhecimento, uma vez que tal material se constitui em um importante instrumento de organização das práticas pedagógicas.

\section{UM OLHAR SOBRE O LIVRO DIDÁTICO}

Compreendemos que o livro didático se constitui em um enunciado vivo, concreto e, portanto, ideológico. Por natureza, a presença do livro didático ${ }^{3}$ em sala de aula, sempre se fez tema para debate. Ainda no século XVII, Comenius (1592-1670) sugeriu a escolarização de todo e qualquer indivíduo, introduzindo o ideal de uma "arte de ensinar tudo a todos", através da sua principal obra: a Didática Magna, através da qual já propunha que fossem produzidos livros exclusivamente para o ensino.

Isso demonstra que o LD há tempos faz parte do ambiente escolar, obviamente não no formato atual, visto que passou por inúmeras transformações na sua produção, forma, edição, conteúdo e organização.

\footnotetext{
O livro didático também foi um importante suporte da organização das práticas escolares. Quando ele não existia, cada aluno devia trazer de sua casa algo escrito - manuscrito ou impresso - que pudesse servir de material de ensino, e este era necessariamente individualizado. A adoção, entre outros materiais, do livro didático único para uma turma inteira possibilitaria o ensino simultâneo, pelo qual muitos passaram a estudar uma mesma matéria ao mesmo tempo (HÉBRARD apud MUNAKATA, 2001, p. 11)
}

Outras modificações foram sendo feitas com o decorrer dos anos e, já na década de 80, através do Decreto $n^{\circ}$ 91.542, de 19 de agosto de 1985, instituiu-se o Programa Nacional do Livro Didático ${ }^{4}$ (PNLD) que preconizava a escolha do LD pelos professores e a sua reutilização. Nos anos seguintes, o programa criou o Guia dos Livros Didáticos e instituiu a avaliação através de categorias para a classificação dos livros.

Instrumento essencial no processo de escolarização, o LD consolidou-se enquanto objeto cultural polêmico e contraditório, dividindo opiniões a respeito de concepção e de sua utilização no cotidiano escolar. Choppin (2004) afirma que estes materiais são "utilitários da sala de aula", elaborados para colaborar no ensino das disciplinas, baseado na inserção gradativa dos conteúdos a serem trabalhados, organizados em unidades ou blocos temáticos que beneficiam o uso seja individual ou coletivamente. 
Por diferentes razões, ele é uma peça muito importante no trabalho pedagógico, definindo sua finalidade, constituindo sua efetividade curricular, bem como "parte do arsenal de instrumentos que compõem a instituição escolar, parte esta, por sua vez, da política educacional, que se insere num contexto histórico e social" (OLIVEIRA; GUIMARÃES; BOMÉNY, 1984, p. 111).

Batista (2003) muito assertivamente define o LD enquanto

um instrumento que favoreça a aprendizagem do aluno, no sentido do domínio do conhecimento e no sentido da reflexão na direção do uso dos conhecimentos escolares para ampliar sua compreensão da realidade e instigá-los a pensar em perspectiva, formulando hipóteses de solução para os problemas atuais. (BATISTA 2003, p. 43)

Esse material tem sido um grande norteador do currículo, e inúmeros professores utilizam-no como a principal ferramenta orientadora de conteúdo. Lajolo (1996) pondera que ele pode ser determinante no processo de aprendizagem, porém quem define a sistematização, a organização e a forma de uso é o professor, juntamente com os alunos e de acordo com o seu contexto social.

Nesta mesma direção, transita Lajolo (1996), quando afirma que

[...] o melhor dos livros não pode competir com o professor: ele, mais do que qualquer livro, sabe quais os aspectos do conhecimento falam mais de perto a seus alunos, que modalidades de exercício e tipos de atividade respondem mais fundo em sua classe e, ainda o caso é que não há livro que seja à prova de professor: o pior livro pode ficar bom na sala de um bom professor e o melhor livro desanda na sala de um mau professor (LAJOLO, 1996, p. 6)

Em nosso país, muitas escolas públicas possuem apenas este material de ensino/aprendizagem e muitos alunos têm o seu primeiro contato com o universo literário através do LD, outros, em toda sua vida, só têm acesso a esse instrumento de conhecimento científico e cultural. Portanto, este material não deve ser depreciado; ao contrário, deve ser valorizado, reconhecido, e sua análise é de extrema relevância, no sentido de conhecer sua abordagem, sua linguagem, sua diversidade e a importância destas, principalmente nessa camada da população. Nesse sentido, Batista (2003), assevera que,

com base nos quais parcelas expressivas da população brasileira realizam uma primeira - e muitas vezes única - inserção na cultura escrita. É, também, um 
dos poucos materiais didáticos presentes cotidianamente na sala de aula, constituindo o conjunto possibilidades com base nas quais a escola seleciona seus saberes, organiza-os, aborda-os. (BATISTA, 2003, p. 30)

Desde 1997, com a publicação dos Parâmetros Curriculares Nacionais (PCNs), os LDs deram início à inclusão do estudo dos gêneros discursivos no ensino de língua materna em nosso país, até porque, com o advento desses documentos, a abordagem dos gêneros textuais tornou-se um critério de aprovação do LD na avaliação do PNLD. Nesse contexto, os PCNs, em particular os de Língua Portuguesa, preconizam que o ensino dessa disciplina deve desenvolver-se a partir dos gêneros textuais, pois o cotidiano dos alunos está permeado deles, aprimorando a competência discursiva dos educandos.

No Brasil, comumente encontramos autores que não concebem a distinção entre os termos gênero discursivo e gênero textual como uma questão apenas terminológica ou seja, para eles a diferença está, sobretudo, na concepção. Assim, sobre gêneros textuais e gêneros discursivos, Rojo apresenta a seguinte observação:

[...] constatamos que podíamos dividir esses trabalhos em duas vertentes metateoricamente diferentes - que, daqui por diante, denominarei teoria de gêneros do discurso ou discursivos e teoria de gêneros de texto ou textuais. Ambas as vertentes encontravam-se enraizadas em diferentes releituras da herança bakhtiniana, sendo que a primeira - teoria dos gêneros do discurso centrava-se sobretudo no estudo das situações de produção dos enunciados ou textos e em seus aspectos sócio-históricos e a segunda - teoria dos gêneros de textos -, na descrição da materialidade textual. (ROJO, 2005, p. 185)

O LD é o principal material que possibilita o contato aos gêneros discursivos, e por isso é basilar na formação de leitores. Em relação aos gêneros discursivos, cabe ressaltar que se diferem dos gêneros textuais, já que aqueles que adotam os gêneros discursivos priorizam a significação dos enunciados, para a acentuação valorativa e o tema, perceptíveis por meio de marcas linguísticas, estilo e forma composicional do texto. Por outro lado, para os que adotam os gêneros textuais, a significação é preterida e abordada apenas em relação ao conteúdo temático (ROJO, 2005).

Por seu impacto sociocultural, o trabalho com os textos multimodais é dever da escola. Logo, é essencial a presença deles no referido material, por contribuírem para que o processo ensino-aprendizagem desenvolva-se em torno da construção de significados que estão para além dos textos exclusivamente verbais e escritos, possibilitando que o aluno aprenda a produzir sentidos, intensificando sua compreensão leitora. 


\section{O PERCURSO METODOLÓGICO}

Para compor o corpus desta pesquisa, inicialmente procuramos identificar qual foi o livro didático de Língua Portuguesa com maior número de escolha na rede estadual de ensino na cidade de Rondonópolis/MT referente aos anos iniciais do Ensino Fundamental, enviado às escolas através do Programa Nacional do Livro Didático (PNLD) para os anos letivos de 2019 a 2022. Isso porque, dada a importância do trabalho com os gêneros multimodais, ao analisar a coleção mais adotada, será possível compreender a realidade da proposta educativa de forma mais concreta.

Para isso, foi realizada uma busca no sítio do FNDE, e os resultados apontaram que das 25 (vinte e cinco) escolas estaduais que ofertam os 05 (cinco) primeiros anos iniciais do Ensino Fundamental, a maioria optou pela coleção Ápis da Editora Ática, de autoria de Ana Trinconi, Terezinha Bertin e Vera Marchesi.

Gráfico 1: Escolha dos livros didáticos nas escolas estaduais em Rondonópolis/MT

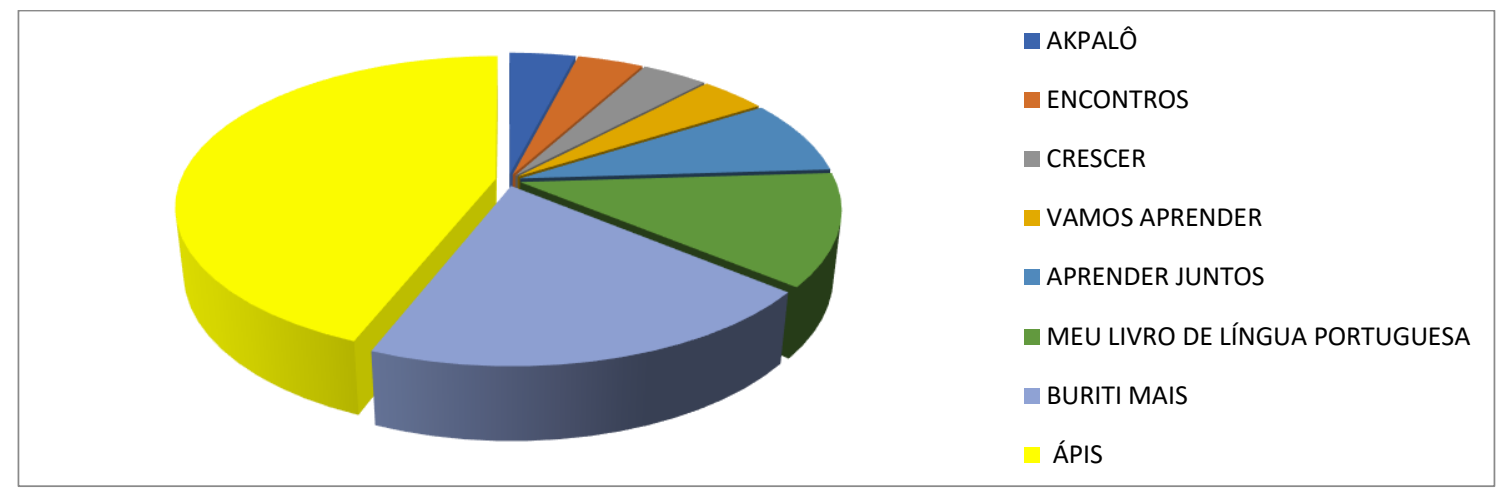

Fonte: Elaborado pela autora com base na coleta de dados.

Na pesquisa, apareceram 08 (oito) títulos escolhidos, deste total 44\% optaram pela Ápis e os $16 \%$ da escolha das escolas estão divididos entre os livros Akpalô, Encontros, Crescer e Vamos Aprender, distribuídos igualmente com 4\% para cada; $8 \%$ escolheram o livro Aprender Juntos; $12 \%$ o Meu Livro de Língua Portuguesa; $20 \%$ o livro Buriti Mais.

Como já se pode observar, as definições de multimodalidade textual são muito amplas, o que nos obriga a estabelecer um recorte para a produção da análise aqui proposta. Consideraremos textos multimodais aqueles que apresentam linguagem verbal 
e não verbal (imagem) simultaneamente, deixando os demais aspectos para um estudo posterior.

\subsection{Visão geral das coletâneas}

Foram analisados os cinco livros didáticos de Língua Portuguesa da Ápis da Editora Ática, correspondentes do $1^{\circ}$ ao $5^{\circ}$ ano, de autoria de Ana Trinconi, Terezinha Bertin e Vera Marchesi, escolhidos através do Guia de Livros Didáticos: PNLD 2019. Por tratarmos dos gêneros multimodais, consideramos de extrema relevância apresentar logo de início a capa de cada um dos volumes, visto que este constitui os gêneros abordados.

Quadro 1: Capa dos livros analisados

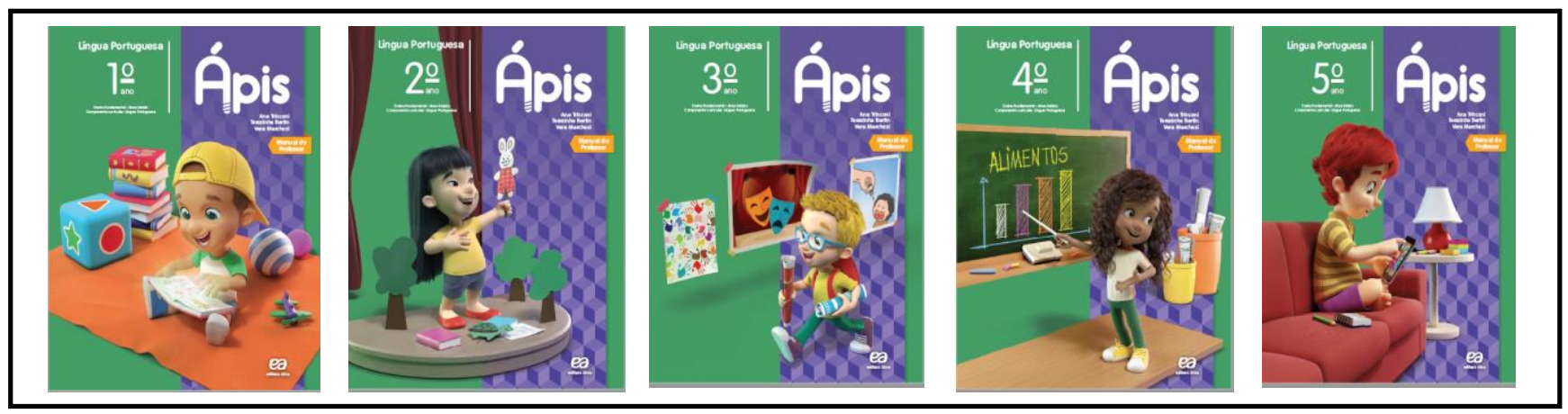

Fonte: Elaborado pela autora com base na coleta de dados.

As crianças que aparecem nas capas possuem, aparentemente, idade correspondente aos alunos que utilizarão os LDs. Acreditamos que tal situação é para que a criança se sinta representada naquele material e, assim, participe de imediato desse processo de ensino. Além disso, a questão da diversidade de gênero e de etnia é contemplada, e todas as crianças estão em situação de aprendizagem, em locais diversos e em contato com materiais distintos, evidenciando prazer, alegria, bons sentimentos; embora não seja tema de discussão deste artigo, consideramos necessário destacar porque também pode vir a ser objeto de análise para um próximo texto.

Inicialmente, as autoras traçam um panorama das demandas educativas em nosso país e esclarecem que o ensino da Língua Portuguesa consiste em suporte de promoção sociocognitiva, visto que possibilita ao sujeito o desenvolvimento de habilidades 
essenciais à apropriação dos conhecimentos sistematizados sobre língua, ou seja, "aquele que se apropria efetivamente da condição de leitor proficiente, de produtor de textos eficientes e de usuário competente da língua nas diversas situações de comunicação orais ou escritas" (TRINCONI; BERTIN; MARCHEZI, 2017, p. VI).

Ao tratar dos propósitos da coleção, Trinconi, Bertin e Marchezi (2017) esclarecem que pretendem "apresentar uma proposta didático-pedagógica que mantenha vivas as interfaces com outras linguagens (verbal, verbo-visual, corporal, multimodal artística, etc.)", introduzindo as noções de multimodalidade. Endossam, ainda, que

[p]ara alcançar esses propósitos com significativo desenvolvimento de atividades em torno de textos de circulação social real - gêneros do discurso diversificados - nos quais se baseiam os estudos e a sistematização dos aspectos de apropriação do sistema de escrita bem como reflexão sobre os usos da língua - oral e escrito. (TRINCONI; BERTIN; MARCHEZI, 2017, p. VI).

Em relação à formação do leitor fluente e proficiente, evocam a importância do trabalho com os gêneros multimodais, nos lembrando de que

\footnotetext{
[a]tualmente as relações de comunicação são caracterizadas pela circulação de grande e diversificado volume de informações de diversas naturezas. Nesse contexto, a capacidade de ler e interpretar textos em variadas linguagens - orais e escritas, verbal e não verbal - é imprescindível, pois, sem ela, torna-se mais difícil, compreender e aproveitar as informações. (TRINCONI; BERTIN; MARCHEZI, 2017, p. X)
}

Nosso objeto de investigação apresenta cinco volumes, sendo que os dois primeiros estão voltados à alfabetização e ao letramento, organizando e sistematizando os processos iniciais de apropriação do sistema de escrita. No terceiro volume, os conteúdos estão dispostos de forma mais complexa em relação ao grau de dificuldade, e, no quarto e no quinto volumes, o aprendizado das habilidades de leitura e escrita são ainda mais intensos em relação ao terceiro volume, visando ao desenvolvimento da aprendizagem da criança.

\subsection{Análise específica de cada LD da coleção}

Prosseguindo com a análise, partimos para a observação do teor de cada um dos volumes. Para tanto, realizamos um levantamento quantitativo dos gêneros textuais de 
forma geral, assim como dos multimodais presentes nos livros seguidos de uma análise qualitativa dos dados observados, sobre os quais passaremos a discorrer.

\subsubsection{Analisando o volume 01}

O LD do $1^{\circ}$ ano está dividido em 22 (vinte e duas) unidades, que se dedicaram ao trabalho com 17 (dezessete) gêneros textuais. Alguns dos gêneros caracterizavam textos multimodais, aliando a linguagem verbal à visual, embora nem sempre fosse a estrutura específica do gênero. Sendo eles: i) texto instrucional: foi realizada uma descrição a partir de uma sequência de imagens, estimulando a leitura de instruções, com ênfase na linguagem não verbal, inserindo-o na classificação dos multimodais; ii) lista: no texto deste volume, se encontra apoiada em pistas gráficas e imagens que auxiliam para que a criança obtenha êxito em sua leitura; iii) receita: o trabalho com tal gênero, que na maioria das vezes é feito apenas utilizando a linguagem verbal escrita, foi realizado por meio do gênero história em quadrinhos, o que consideramos uma perspectiva muita positiva, visto que reforça o ensino por meio da intergenericidade, acrescentando saberes ao aluno.

Já os gêneros pintura e legenda foram considerados na perspectiva da modalidade, porque ambos somente apareceram juntos, embora fossem destaques de unidades de forma separada. $\mathrm{O}$ trabalho com o gênero pintura permite um tipo de leitura que demanda determinadas habilidades para observar detalhes como formas, cores e traços, sendo essenciais nas práticas de letramento, pois contribuem para o desenvolvimento do universo cultural da criança. A respeito do gênero legenda, Costa (2008) nos elucida que

[...] é um texto breve, objetivo, em cujo enunciado predomina a frase nominal, que serve para acrescentar informações a imagem publicada ou ratifica a informação dada visualmente. Pode ser exibido ao lado, abaixo ou dentro dessa imagem (foto, gráfico, ilustração, etc.). (COSTA, 2008, p. 124)

Foram encontrados gêneros "genuinamente" multimodais, isto é, aqueles que necessariamente abrigam linguagem verbo-visual, a saber: i) capa de livro: texto em linguagem multimodal em que se alia a linguagem verbal ao imagético; ii) história em quadrinhos: é um exemplo de gênero multimodal, pois aglutina diversos tipos de linguagens (verbal, gestual, visual, sonora) em um único texto. Geralmente, a HQ é 
conhecida pela maioria dos alunos, o que auxilia na compreensão da constituição da estrutura narrativa e estimula a construção de sentido através da sequência de imagens, sendo também uma forma de entretenimento e diversão; iii) história: as autoras assim nominaram as conhecidas "historinhas de literatura infantil", um texto narrativo permeado de elementos como personagens, tempo, espaço e ações. Para compor o conteúdo do LD, trouxeram um livro de histórias na íntegra, caracterizando um gênero multimodal; iv) cartaz: gênero discursivo multimodal, que visa anunciar alguma coisa ou divulgar algo de interesse público, que se utiliza de linguagem verbo-visual, unindo imagens e palavras para passar uma mensagem.

Há que se ressaltar, ainda, que os gêneros letra de canção e cantiga popular, embora sejam produtos da junção das linguagens verbal e musical - ou seja, composto de duas semioses, logo, um gênero multimodal -, não se enquadram em nosso recorte neste trabalho que investiga os gêneros multimodais verbo-visuais.

\subsubsection{Analisando o volume 02}

No $2^{\circ}$ ano, o LD encontra-se dividido em 12 (doze) unidades, voltadas ao trabalho com 11 (onze) gêneros textuais. Neste volume, foi dado um maior enfoque aos gêneros de predominância da linguagem verbal na introdução às unidades, o que nos faz acreditar que seja por conta da continuidade ao processo de alfabetização dos alunos, embora não considere as práticas de múltiplos letramentos que os gêneros multimodais possibilitam na formação discente desde a mais tenra idade.

Encontramos também o gênero carta pessoal, que, diferentemente do gênero poema, foi abordado de maneira verbo-visual, em que a linguagem verbal interage completamente com a imagética. Nas atividades que formavam a sequência didática em questão, as autoras se utilizaram de recursos em uma perspectiva de intergenericidade e hibridismo, fazendo referência a outros gêneros, como o e-mail e as mensagens instantâneas pelo celular (SMS, conversas por redes sociais), uma vez que estas são novas formas de comunicação em meios eletrônicos que fazem parte do cotidiano do aluno.

O gênero gráfico informativo ou infográfico também foi incluído, unindo textos e imagens de forma dinâmica. Muito utilizado pelas mídias devido a suas múltiplas linguagens, este gênero tem invadido o ambiente escolar, dado às diversas estratégias 
didáticas que podem ser exploradas por meio dele, pois admite que a leitura seja feita de modo não linear, ou seja, da maneira que motive mais os alunos, ajudando-os em uma leitura mais plena e no aprimoramento da compreensão leitora.

Destarte, é fundamental destacar que, a partir desse volume, foi inserida uma seção denominada "Hora de organizar o que estudamos", na qual todo conteúdo abordado é sintetizado por meio de mapas conceituais. O gênero trabalhado é estruturado em esquemas que organizam visualmente o que foi estudado. Essa união do verbal com o visual está em conformidade com a perspectiva da multimodalidade, na constituição de múltiplos letramentos, que é tema deste estudo.

\section{$\underline{4.2 .3 \text { Analisando o volume } 03}$}

O LD destinado ao $3^{\circ}$ ano possui 12 (doze) unidades, dedicando-se ao trabalho com o mesmo número de gêneros discursivos. $\mathrm{O}$ trabalho pedagógico com os gêneros multissemióticos neste volume teve uma crescente em relação ao anterior.

Os gêneros HQ e carta pessoal foram abordados novamente, além das formas de correspondência mais simples, como o bilhete - também já trabalhado anteriormente -, optou-se por se valer de um texto multimodal, literário e ficcional. Aborda o gênero cartaz publicitário, gênero tipicamente multimodal, trabalhado de forma genérica no $1^{\circ}$ ano e retornando com mais profundidade, que engloba diferentes linguagens em sua composição.

Encontramos também o gênero notícia, que é o texto falado ou escrito da esfera jornalística, divulgado pelos diversos meios de comunicação (jornal, revista, rádio, TV, sites, etc.). Nele, são relatados fatos atuais verídicos, de forma clara e objetiva, e sua didatização auxilia no desenvolvimento de habilidades fundamentais para os gêneros orais.

\subsubsection{Analisando o volume 04}

Este volume está composto de 08 (oito) unidades. Nessa fase, as autoras reduziram a quantidade de unidades no LD e aumentaram o tamanho dos textos e a quantidade de atividades, que agora têm outra seção destinadas à leitura e à compreensão textual. 
Versa sobre o gênero diário pessoal, no qual as autoras deram preferência ao trabalho com um diário fictício, preservando a forma de expressão e a linguagem, mais espontânea e informal, de um diário real.

O gênero reportagem, que expõe informações baseadas em investigação e pesquisa, visa informar o leitor com mais detalhes e maior profundidade do que a notícia, em alguns casos, por meio de dados, gráficos, mapas, boxes ou entrevistas.

O gênero mapa objetiva orientar o leitor, congregando informações e as convertendo em linguagem visual. Já o gênero roteiro intenciona instruir, orientar e prescrever formas de agir do leitor ou de realizar atividades diversas, descrevendo ações. No LD em questão, o mapa e o roteiro de passeio são trabalhados enquanto gêneros complementares do agrupamento de instruir, proporcionando ao aluno a oportunidade de ler e interpretar informações em uma linguagem própria dos mapas e dos roteiros de passeios turísticos.

\section{$\underline{4.2 .5}$ Analisando o volume 05}

O último volume da coleção analisada possui 08 (oito) unidades, com os seguintes gêneros em formato multimodal: i) poema, com a linguagem verbal vinculada à não verbal, agregando diferentes formas de representação - palavras e recursos visuais/ gráficos - na constituição de sentidos e, portanto, caracterizando-se texto multimodal, o que não ocorreu como os textos trabalhados anteriormente sobre tal gênero discursivo; ii) o gênero texto informativo, trazido para o volume englobando distintas maneiras de tratamento da informação, organizado em boxes e aliado a imagens, ressaltando seus aspectos multimodais e viabilizando a realização de uma leitura não linear; iii) o gênero artigo de opinião, um texto jornalístico com identificação do autor e que busca expor uma opinião a respeito de um assunto determinado, apresentando argumentos que justifiquem o seu posicionamento; iv) o gênero reportagem, que demonstrou bastante riqueza em recursos multimodais, entremeando a linguagem verbal (texto escrito) com a linguagem visual presente nas fotografias, reproduzindo uma reportagem verídica no LD; e v) o gênero propaganda, que são, na sua grande maioria, multimodais, porquanto associam diversos elementos representativos e recursos verbo-visuais, propagando sua mensagem por meio de múltiplas linguagens, segundo seus respectivos suportes. O 
desenvolvimento do trabalho com este gênero desperta no aluno a criticidade sobre a intenção de cada anunciante ao divulgar e criar uma propaganda.

\subsection{Frequência de aparição dos textos/gêneros multimodais na coleção}

Compreendemos que, no intuito de aproximar o aluno dos discursos que incidem em seu meio social, ou seja, para além da sala de aula, em inúmeras possibilidades comunicativas, assim como auxiliar no desenvolvimento de habilidades que permitam a utilização dos gêneros discursivos multimodais, com competência nas interações sociais físicas ou digitais, é fundamental que o trabalho pedagógico seja construído a partir da diversidade de gêneros existentes nas distintas esferas de comunicação.

Gráfico 2: Gêneros multimodais na abertura das unidades

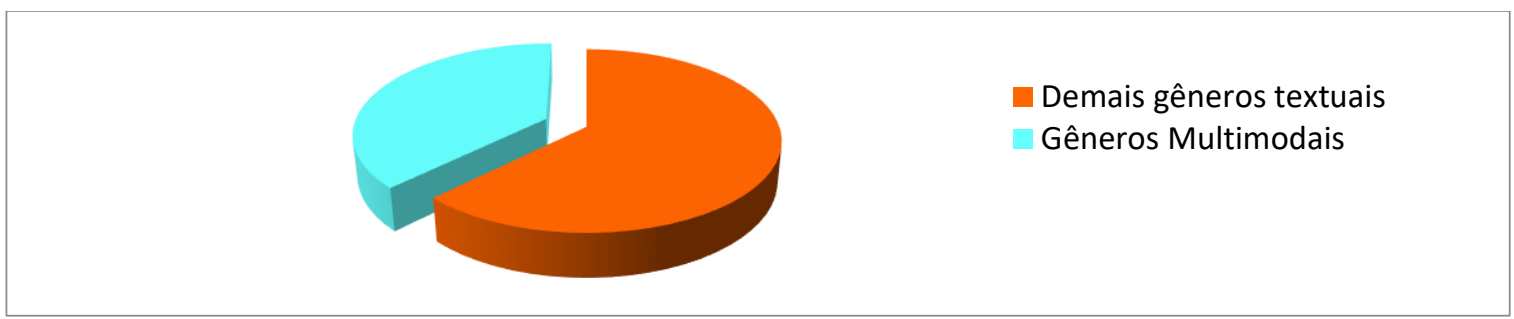

Fonte: Elaborado pela autora com base na coleta de dados.

A coleção está estruturada em torno de 56 gêneros textuais - destes, 21 são multimodais, ou seja, apenas $38 \%$ da coleção está voltada para o letramento multimodal dos alunos. Neste contexto, podemos observar que no $1^{\circ}$ e no $5^{\circ}$ anos ocorreu a maior concentração de diversidade de gêneros multissemióticos, nosso objeto de análise, com percentuais de $59 \%$ e $63 \%$, respectivamente. Uma queda brusca no percentual ocorre no $2^{\circ}$ ano $(25 \%)$ e no $3^{\circ}$ ano (33\%), obtendo uma evolução no $4^{\circ}$ ano $(38 \%)$, conforme o gráfico abaixo: 
Gráfico 3: Gêneros multimodais na abertura das unidades - divisão por ano

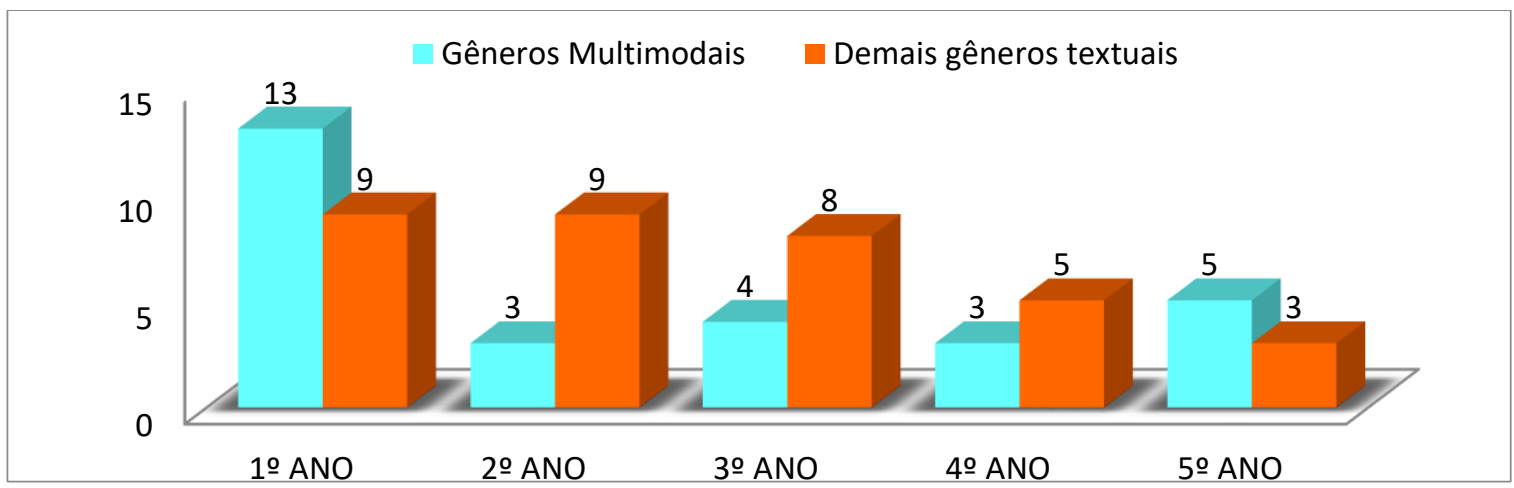

Fonte: Elaborado pela autora com base na coleta de dados.

Embora o $5^{\circ}$ ano apresente percentual maior, o número de gêneros trabalhados no volume corresponde a menos da metade do que no $1^{\circ}$ ano, fase em que os gêneros textuais dinamizaram o LD. Em seguida, contabilizamos em toda coleção um total de 597 textos multimodais divididos em 38 gêneros, sendo que $16 \%$ deles estão no LD do $1^{\circ}$ ano, $24 \%$ no $2^{\circ}$ ano, $16 \%$ no $3^{\circ}$ ano, $25 \%$ no $4^{\circ}$ ano e $19 \%$ no $5^{\circ}$ ano.

Gráfico 4: Gêneros multimodais em toda coleção

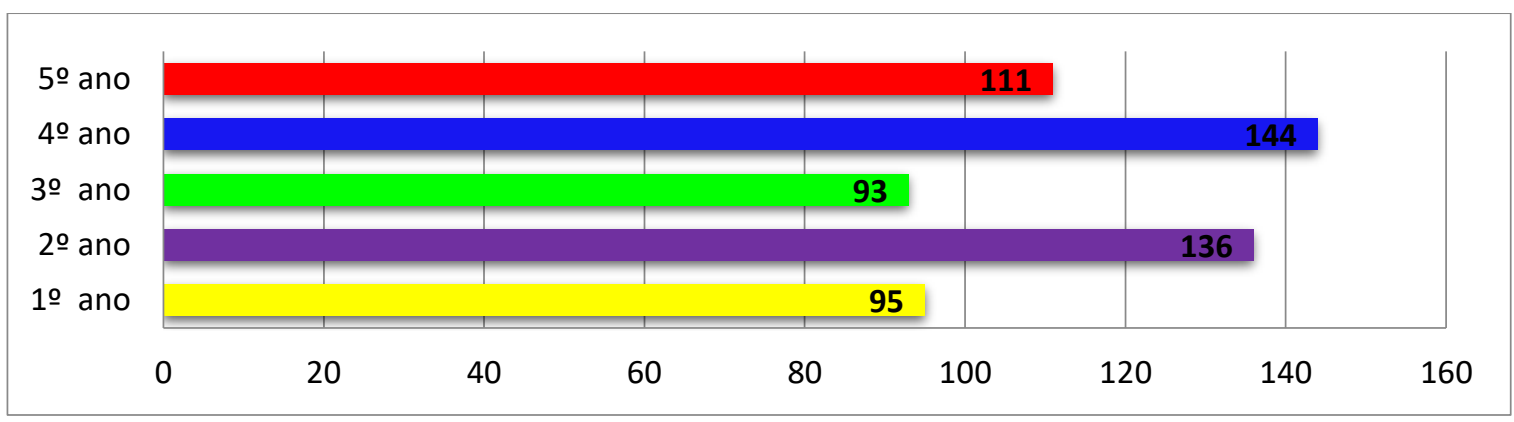

Fonte: Elaborado pela autora com base na coleta de dados.

Isto nos permite afirmar que as quantidades bem distribuídas no LD oportunizam o maior contato com a multimodalidade, pois consideramos que, para que haja êxito no aprendizado e impacto em seu meio comunicativo, o aluno precisa conhecer e saber fazer uso de inúmeros gêneros discursivos.

No volume 01, foram 95 textos multissemióticos distribuídos em 12 gêneros multimodais, sendo o gênero fotografia o de maior frequência, ocupando $62 \%$ de manifestação em relação aos outros 11 gêneros que pudemos visualizar. Por se tratar do 
início do processo de alfabetização, tal gênero possibilita maior interação e construção de sentido para o aluno, devido à sua baixa complexidade de compreensão.

No volume 02, foram 136 textos verbo-visuais, distribuídos em 13 gêneros multimodais e, como no LD anterior, o gênero fotografia ainda é mais evidente, com $52 \%$ de presença neste volume, e endossamos nossa concepção de menor nível de abstração para o trato com tal gênero enquanto justificativa para tais dados. Os gêneros enfocados são praticamente os mesmos do $1^{\circ}$ ano, porém acrescentados os de predominância digital como o infográfico e a notícia em site, enriquecendo o contato dos alunos com a multimodalidade das mídias tecnológicas.

No volume 03, pudemos observar 93 textos multimodais, distribuídos em 18 gêneros, e com bastante destaque para o gênero capa de livro, que aparece por 29 vezes, perfazendo um percentual de $35 \%$ da unidade, seguido do gênero tirinha com $20 \%$, sendo que os outros 16 gêneros ocupam os $45 \%$ restante do volume. Embora em quantidade mínima, vale ressaltar a inserção do gênero haikai neste LD enquanto conhecimento de gêneros que ainda não fazem parte do cotidiano do aluno, possibilitando novos letramentos. Este é um gênero de origem japonesa que possui a forma de poemas curtos, em sua maioria, ligados à natureza, sem imposição de rimas, construindo imagens. Surgiram da noção de que os sentimentos podem ser expressos para além da linguagem verbal, ou seja, usam as palavras para formar imagens e interagir com as demais.

Já no volume 04 , os 144 textos multissemióticos encontrados dividem-se em 23 gêneros com aspectos bastante diferenciados, colaborando para um excelente desenvolvimento do processo de ensino-aprendizagem. É notória a profusão de gêneros multimodais, que vão desde aqueles de circulação nas mídias digitais (como o blog, o mapa digital e o infográfico) até os mais tradicionais como a literatura de cordel, englobando agrupamentos diversificados que favorecem o desenvolvimento das inúmeras competências discursivas nas situações de interação social a que o aluno está exposto. $\mathrm{O}$ gênero fotografia lidera mais uma vez, representando uma frequência de $31 \%$ na composição do LD, seguido da capa de livro com $17 \%$ e da tirinha com 14\%, restando $38 \%$ aos demais 20 gêneros.

Por último, o volume 05 contou com 111 textos verbo-visuais, divididos também em 23 gêneros. Assim como no volume passado, apresentou um repertório multimodal bem eclético, em que a tríade (tirinha, capa de livro e fotografia) desempenha um papel 
de destaque, com $67 \%$ dos textos que compõem o volume $(32 \%, 23 \%$ e $12 \%$ respectivamente).

A saber, os gêneros a que nos referimos são: capa de livro (116 vezes), HQ (25), tirinha (79) e fotografia (202), que estão dispostos no material da seguinte forma:

Gráfico 5: Gêneros multimodais mais recorrentes em toda coleção

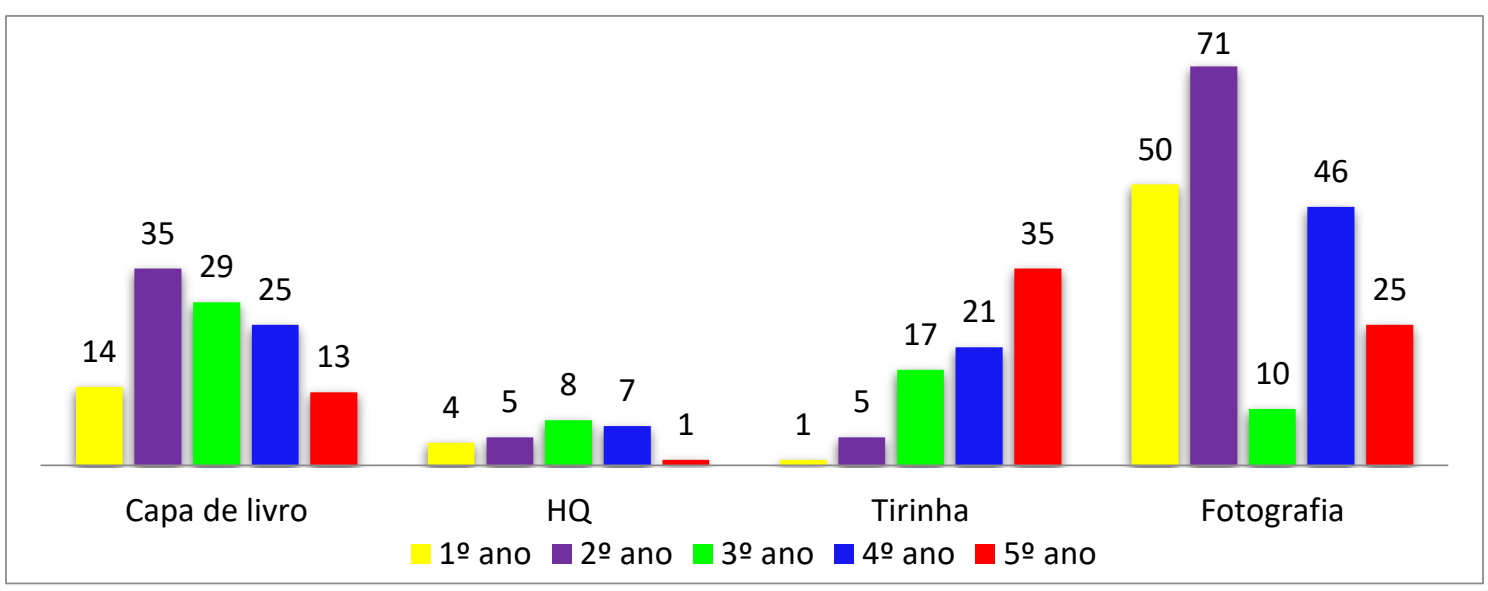

Fonte: Elaborado pela autora com base na coleta de dados.

Isto significa que, do total de 38 tipos de gêneros, $71 \%$ referem-se a essas 04 modalidades mencionadas e os $29 \%$ restantes estão distribuídos nos outros 34 tipos, demonstrando um privilégio dado pelas autoras a uns gêneros em detrimento de outros.

\subsection{A multimodalidade nas seções}

\subsubsection{Seção "Aí vem...”}

Esta seção visa ampliar o universo cultural da criança e também proporcionar deleite no momento da leitura, através de textos complementares geralmente do mesmo gênero estudado na unidade, auxiliando o aluno na construção do conceito, embasado em outros textos com características diferentes, numa perspectiva de intertextualidade. Objetiva também colaborar nas práticas de letramentos por meio de textos de circulação real que permeiam o cotidiano dos alunos.

Em toda a coleção, das 62 unidades, 40 apresentaram esta seção com gêneros variados. No entanto, destes, apenas 12 caracterizavam-se como textos multimodais. Os 
textos multissemióticos desta seção foram propagados por meio dos gêneros história (que materializou 2 textos, sendo um mesclado a pictogramas), cantiga popular, lenga-lenga, gráfico informativo, carta pessoal, blog pessoal, reportagem, carta, mapa de roteiro turístico e poema.

\subsubsection{Seção "Outras linguagens"}

Os livros do $3^{\circ}, 4^{\circ}$ e $5^{\circ}$ anos possuem uma seção nomeada "Outras Linguagens" que, de acordo com as autoras,

[...] favorece a intertextualidade por meio de leituras sobre textos diversos e, muitas vezes, em diferentes linguagens ao mesmo tempo - textos multimodais. [...] relaciona-se os gêneros estudados com atividades orais para percepção de diferentes formas de expressão, principalmente das linguagens não verbais. (TRINCONI; BERTIN; MARCHEZI, 2017, p. XX)

De acordo com o manual, privilegia-se a leitura de textos, principalmente de linguagem não verbal (multimodais) em formatos distintos (telas, fotos, ilustrações, cartoons, tirinha, infográficos, mapas e outros) para que o aluno possa relacionar os gêneros textuais estudados a textos em outras linguagens no seu cotidiano, expandindo suas vivências sociais a partir de diferentes maneiras de se comunicar.

Pudemos observar também que as escolhas autorais desta coleção concentram-se em alguns gêneros específicos. Sobre isso, Mendonça (2007) afirma que

[...] os gêneros podem e devem ser retomados em mais de uma série, desde que sejam apresentados novos desafios para os alunos. Dessa forma, não haverá uma "repetição de assuntos", mas uma nova oportunidade de produzir conhecimento e desenvolver habilidades e competências cada vez mais complexas, que poderão ser aplicadas a outras situações/gêneros. (MENDONÇA, 2007, p. 85)

Desse modo, podemos inferir que estes possam se estabelecer enquanto elementos facilitadores do desenvolvimento das habilidades leitoras concernentes aos textos verbais, bem como auxiliar em outros letramentos, integrando as diversas linguagens, pois as atividades de leitura ou escrita que os acompanham apresentam um movimento gradativo e progressivo. 


\subsubsection{Seção "Projetos de Leitura"}

A coleção analisada possui uma seção que se configura em um projeto didático de leitura, cujo objetivo, conforme as autoras, é o de proporcionar um meio para contribuir com a valorização da literatura pelo aluno, criando possibilidades para que o leitor enseje ampliar seus conhecimentos de maneira prazerosa. Após a efetivação da leitura, são propostas oficinas diversas e lúdicas para que a criança se aproprie dos saberes gerados através da experiência, estimulando a competência e a compreensão leitora, assim como favorecendo o despertar do senso crítico através dos debates e comentários.

A partir disso, foi possível observar que, no trabalho com o livro de história texto multimodal -, a articulação das inúmeras linguagens (visual, verbal, matemática, etc.) era bastante notória, conquanto a criança que ainda não domina com propriedade o texto escrito, mas gosta de ouvir histórias e manipular os livros de textos multimodais obtém uma progressão bastante positiva em seu aprendizado. O que não se verificou na antologia, em que os textos eram totalmente verbais, não privilegiando as atividades de letramento, em uma prática social real que está permeada das multissemioses.

Os gêneros multimodais ocuparam apenas $12 \%$ de todos os demais gêneros da seção, representados pelos livros: "O menino que descobriu as palavras" - Cinéas Santos ( $1^{\circ}$ ano), "O que é que te diverte" - Eliardo França ( $2^{\circ}$ ano) e "O menino e o muro" Sônia Junqueira ( $3^{\circ}$ ano). Os $88 \%$ restante dividiram-se entre os gêneros fábula, texto informativo, cordel, história, conto, letra de canção, texto científico e poema, este último materializado em 07 textos.

\subsection{Aspectos gerais da análise}

Os textos multimodais aliam várias semioses que interagem entre si na construção de significados, e sua expansão têm sido uma crescente devido às demandas sociais e tecnológicas a que estamos expostos.

Nesse cenário, a escola necessita favorecer o desenvolvimento de habilidades para ler essas múltiplas linguagens atribuindo sentido ao que lê, e utilizando essas práticas de leitura em situações cotidianas. Desse modo, a escola precisa priorizar o trabalho com 
estes gêneros, pois as imagens não podem mais ser concebidas apenas como um adorno da palavra, um meio de comunicação inferior ao texto verbal.

Gráfico 6: Interação entre texto verbal e imagem

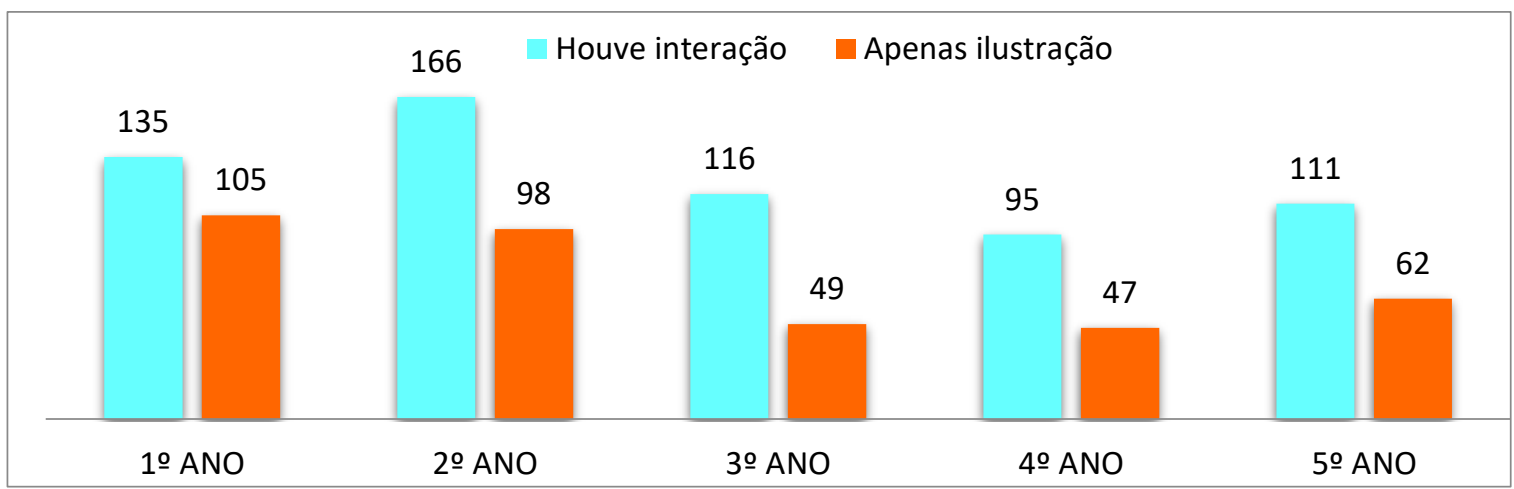

Fonte: Elaborado pela autora com base na coleta de dados.

Entre os textos/gêneros multissemióticos presentes na coleção, buscamos verificar a articulação entre as linguagens verbais e visuais e se as imagens interagiam com as palavras, se englobavam ou direcionavam para aquela, de modo que os significados fossem constituídos a partir do todo. Nessa direção, pudemos constatar que $63 \%$ dos textos que se valem de múltiplas semioses o fazem de forma interativa e articulada, enfatizando a inter-relação de ambos na construção de sentido, contra apenas $37 \%$ daquelas em que as imagens eram apenas uma "figura" adicionada aleatoriamente.

Gráfico 7: Exploração da imagem nas atividades de leitura

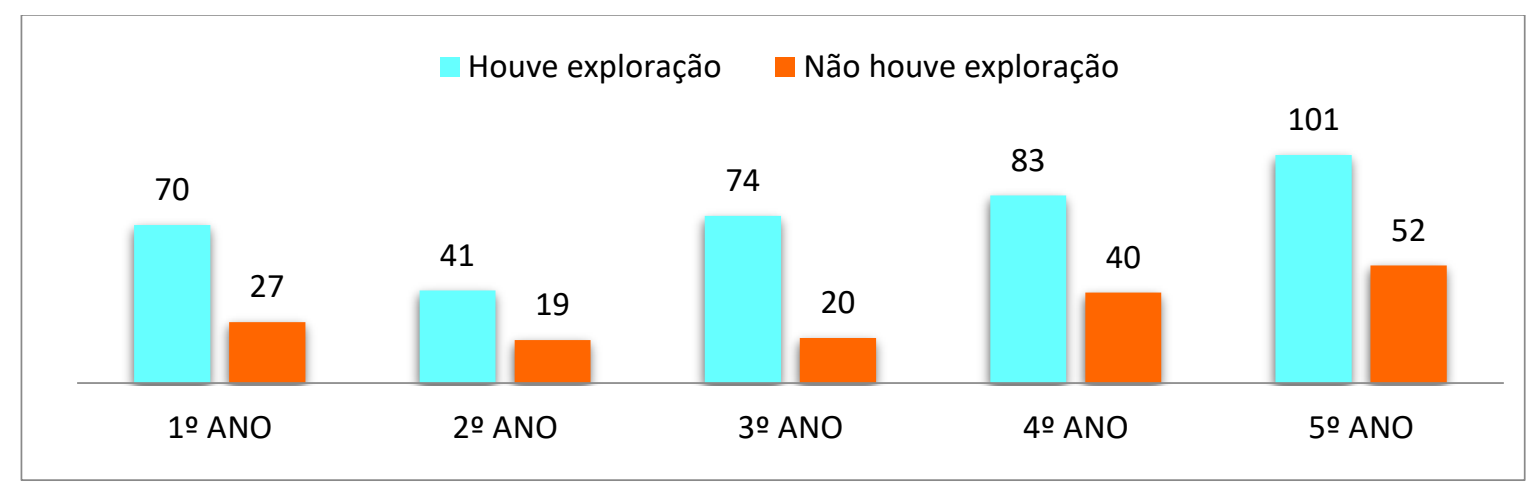

Fonte: Elaborado pela autora com base na coleta de dados.

Os resultados revelaram que, em $70 \%$ das atividades de leitura, as imagens eram exploradas em associação ao texto verbal, em um fluxo dinâmico e multimodal, no qual 
a interpretação de uma linguagem demandava a presença da outra, enfocando o processo de leitura num movimento dialógico de elementos semióticos conectados.

De igual modo, foi conduzido com as atividades de escrita onde estavam inseridas imagens na sua estrutura, intencionando identificar como as diversas semioses se relacionam para criar significados a partir das situações utilizadas no LD.

Gráfico 8: Exploração da imagem nas atividades de escrita

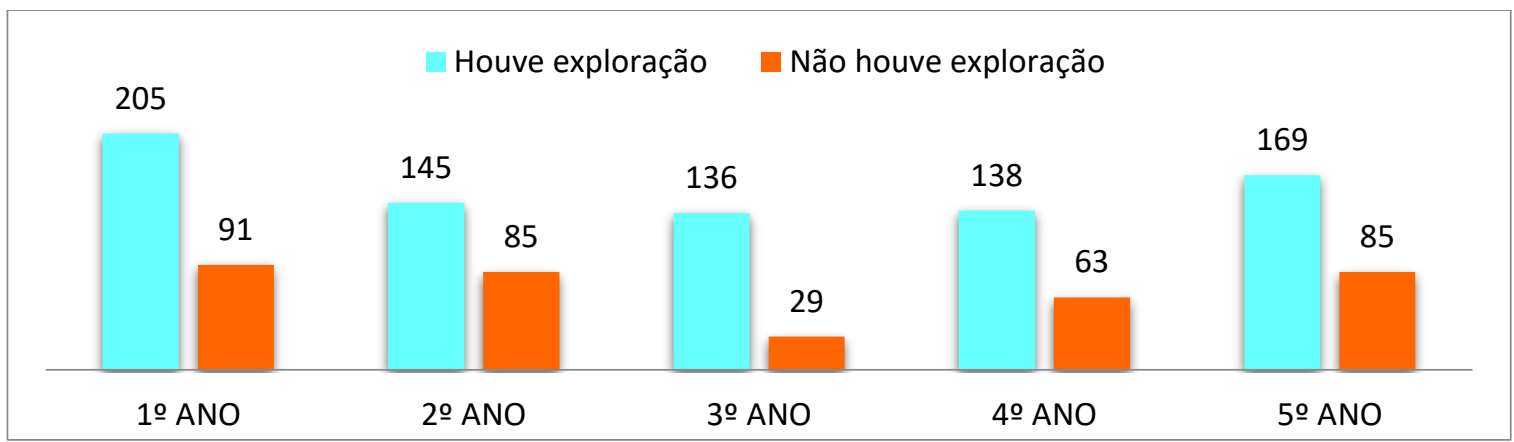

Fonte: Elaborado pela autora com base na coleta de dados.

E também de igual modo, os resultados demonstraram que a grande maioria das atividades de escrita adotam uma perspectiva multimodal. Cabe lembrar que as atividades de escrita são muito mais numerosas do que as de leitura, o que ao nosso ver denota maior enfoque no texto verbal. No entanto, isso pode ser apenas uma subjetividade, visto que $69 \%$ das atividades faziam referência às imagens na compreensão necessária para a realização da mesma.

\section{CONSIDERAÇÕES FINAIS}

Os LDs analisados apresentam uma diversidade de gêneros textuais, e consideramos muito válida sua proposta para o letramento multimodal. No entanto, as autoras prendem-se bastante ao que preconiza a Base Nacional Curricular Comum (BNCC), fazendo repetitivas referências às habilidades tratadas neste documento. Isso nos leva a pressupor que os aspectos positivos encontrados aparentam apenas um cumprimento às exigências impostas pelas regras de concorrência ao Edital/PNLD, como tratado por alguns autores sobre a questão de mercado editorial, que não é nosso foco de investigação, mas que nos chamou atenção. 
Outro ponto a mencionar é sobre a questão do excesso de atividades voltadas ao ensino da gramática a partir do $3^{\circ}$ ano, sendo que, em muitos casos, o imagético foi utilizado para tais fins. Notamos também que, nos LDs voltados aos $4^{\circ}$ e $5^{\circ}$ anos, além de os aspectos gramaticais estarem mais complexos, isto é, difíceis e exigindo maior abstração por parte dos alunos, os conteúdos ortográficos também ganharam um grande espaço.

Nossa crítica é em relação à quantidade exacerbada desse tipo de atividades em uma fase de consolidação do processo de apropriação da leitura e da escrita, principalmente por isso se dar em um viés tradicionalista de exercícios descontextualizados e soltos, como foi verificado algumas vezes.

É bem verdade que o livro didático por si não é suficiente para suprir as exigências das práticas didático-pedagógicas que o processo de ensino-aprendizagem exige, assim como o fato de os gêneros multimodais ocuparem o LD não significar a apropriação de novas práticas de letramento. Antes, é necessário que a escola e o professor assumam uma postura ativa nesse sentido, com vistas a garantir o desenvolvimento da capacidade de observação dos gêneros, interligando-as os conceitos estudados e os contextualizando, ou serão apenas mais uma "figura" para a criança olhar.

É fundamental que o aluno compreenda o funcionamento do processo de interação entre as múltiplas linguagens dos textos multimodais e, de posse de tais saberes, adquiram outros muitos letramentos adquirindo consciência crítica e tornando-se um sujeito reflexivo, protagonista e democrático.

\section{Referências}

BAKHTIN, M. Os gêneros do discurso In: Estética da criação verbal. Tradução (do francês) por PEREIRA, M.E.G, $2^{a}$ ed. São Paulo: Martins Fontes, 2008.

BATISTA, A. A. G. A avaliação dos livros didáticos: para entender o Programa Nacional do Livro Didático (PNLD). In: ROJO, R. H. R.; BATISTA, A. A. G. (Org.) Livro Didático de Língua Portuguesa: letramento e cultura da escrita. Campinas: Mercado de Letras, 2003. p. 25-68.

BAZERMAN, C. Géneros textuales, tipificación y actividad géneros textuales, tipificación y actividad. Puebla, México: Benemérita Universidad Autónoma de Puebla Benemérita Universidad Autónoma de Puebla, 2012, p. 122-158. Disponível em 
https://www.researchgate.net/publication/269222521_GENEROS_TEXTUALES_TIPI FICACION_Y_ACTIVIDAD. Acesso em 22 nov. 2019.

BRASIL. Ministério da Educação. Secretaria de Educação Básica. Parâmetros Curriculares Nacionais: Língua Portuguesa - 1ª a $4^{\text {a }}$ série. Brasília: SEF/MEC, 1997.

BRASIL. Ministério da Educação. Secretaria de Educação Básica. Guia do Livro Didático 2019. Alfabetização. Brasília, 2018.

BUNZEN, C. Livro didático de língua portuguesa: um gênero do discurso. 2005. $170 \mathrm{f}$. Dissertação (Mestrado em Letras) - Universidade Federal de Campinas, Campinas, 2005.

BRONCKART, J. P. Atividade de linguagem, textos e discursos. Por um interacionismo sócio discursivo. São Paulo: Educ., 1999

CHOPPIN, A. História dos livros e das edições didáticas: sobre o estado da arte. Educação e Pesquisa, São Paulo, v. 30, n. 3, set.-dez., 2004. Disponível em: http://www.revistas.usp.br/ep/article/view/27957/29729. Acesso em 22 nov. 2019.

COSTA, S. R. Dicionário de gêneros textuais. Belo Horizonte: Autêntica, 2008

DELL'ISOLA, R. L. P. Intergenericidade e Agência: quando um gênero é mais do que um gênero. 2007. (Apresentação de Trabalho/Comunicação).

DIONISIO, A. P.; MACHADO, A. R.; BEZERRA, M. A. Gêneros Textuais \& Ensino. $2^{\mathrm{a}}$ ed. Rio de Janeiro: Lucerna, 2014

DIONISIO, A. P. Gêneros multimodais e multiletramento. In: KARXOSKI, B.G. \& BRITO, K. S. (orgs.) Gêneros textuais: reflexões e ensino. $3^{\mathrm{a}}$ ed. Rio de Janeiro: Nova Fronteira, 2005. p. 119-132.

DOLZ, J.; SCHNEUWLY, B. Gêneros orais e escritos na escola. Tradução e organização Roxane Rojo e Glaís S. Cordeiro. Campinas, SP: Mercado das Letras, 2011.

GATTI, B. Pesquisar em educação: considerações sobre alguns pontos-chave. Revista Diálogo Educação, Curitiba, v. 6, n. 19, p. 25-35, set./dez. 2006

KLEIMAN, A. B. (org.). Os significados do letramento: uma nova perspectiva sobre a prática social da escrita. Campinas, SP: Mercado das Letras, 1995.

LAJOLO, M. Livro didático: um (quase) manual de usuário. Em Aberto, n. 69. jan./mar., 1996. Texto disponível na Internet: http://www.inep.gov.br/pesquisa/publicações. Acesso em 26 out. 2003.

MARCUSCHI, L. A. Produção textual, análise de gêneros e compreensão. São Paulo: Parábola Editorial, 2008 
MAROUN, C. R. G. B. A multimodalidade textual no livro didático de português. 2006. 118 f. Dissertação. Universidade de Brasília. Programa de Pós-Graduação em Linguística. Mestrado em Linguística. Disponível em: https://repositorio.unb.br/bitstream/10482/8854/1/2006_CristianeRibeiroGomesBouMar oun.pdf. Acesso em 27 de nov. de 2019.

MENDONÇA, M. Análise lingüística: refletindo sobre o que há de especial nos gêneros In: SANTOS, C. F.; MENDONÇA, M.; CAVALCANTI, M. C. B. Diversidade textual: os gêneros na sala de aula. 1.ed. Belo Horizonte: Autêntica, 2007.

MUNAKATA, K. Livro didático e formação do professor são incompatíveis? Congresso Brasileiro de Qualidade em Educação: formação de professores. Brasília: MEC, SEF, 2001.

OLIVEIRA, J. B. A.; GUIMARÃES, S. D. P.; BOMÉNY, H. M. B. A política do livro didático. São Paulo: Sammus, 1984.

PAES de BARROS, C. G. Capacidades de leitura de textos multimodais. Polifonia, Cuiabá, n. 19, p. 161-186, 1. sem. 2009.

PAES de BARROS, C. G.; COSTA, E. P. M. da. Os gêneros multimodais em livros didáticos: formação para o letramento visual? Bakhtiniana, Revista de Estudos do Discurso [online], vol.7, n.2, p. 38-56, 2012.

ROJO, R.; BATISTA, A. G. (ORG.). Livro didático de língua portuguesa, letramento e cultura da escrita. Campinas: Mercado de Letras, 2003.

; BARBOSA, J. P. Hipermodernidade, multiletramentos e gêneros discursivos. São Paulo: Parábola Editorial, 2015

Livro em Sala de Aula: modo de usar. Materiais didáticos: escolha e uso. Programa Salto para o Futuro. Boletim 14. Agosto de 2005.

A teoria dos gêneros discursivos do Círculo de Bakhtin e os multiletramentos. In: DE PAULA, L.; STAFUZZA, G. (Orgs.) Círculo de Bakhtin: inter e intra discursividades. Vol. 4 da Série Bakhtin - Inclassificável. Campinas: Mercado de Letras, 2010.

SOARES, M. Letramento: um tema em três gêneros. Belo Horizonte, Autêntica, 1998.

TRINCONI, A. M.; BERTIN, T. C. H.; MARCHEZI, V. L. C. Ápis: Língua Portuguesa. $1^{\circ}, 2^{\circ}, 3^{\circ}, 4^{\circ}$ e $5^{\circ}$ ano: Ensino Fundamental, Anos Iniciais. $3^{a}$ ed. São Paulo: Ática, 2017. 


\begin{abstract}
${ }^{1}$ Segundo a semiótica social, a língua faz parte de um contexto sociocultural no qual a cultura é produto de um processo de construção social. Nessa medida, nenhuma modalidade de linguagem pode ser inteiramente estudada de maneira isolada. A língua - falada ou escrita - não pode ser entendida senão ligada a outros modos de representação que participam da composição de um texto. (PAES DE BARROS, 2009, p. 162)
\end{abstract}

${ }^{2}$ Gunther Kress é professor de Semiótica e de Educação, no Departamento de Aprendizagem, Currículo e Comunicação do Instituto de Educação na Universidade de Londres. Lidera o grupo de pesquisa Cultura, Comunicação e Sociedades. Discute a complexidade do entendimento da linguagem escrita quando empregada isoladamente sem a comunhão de outros modos semióticos em determinado discurso. Segundo o autor, cada modo empregado em um discurso multimodal, tem função específica, com potencial distinto para a construção do significado. Ele avança nos estudos sobre a Multimodalidade em relação à abordagem da Semiótica Social para o estudo da comunicação contemporânea, já apresentada na obra de $2001 \mathrm{em}$ coautoria com Van Leeuwen, na qual enfatizam que o significado é construído de diferentes maneiras, sempre, em diferentes modos e mídias presentes em conjunto comunicacional, centrado nos recursos semióticos de comunicação e nas práticas comunicativas. Assim, criam a teoria semiótica social da multimodalidade, adequada à prática semiótica contemporânea. (Informações obtidas em: http://www.ufjf.br/revistaveredas/files/2012/10/resenha-1.pdf)

${ }^{3}$ Doravante representado pelas iniciais "LD".

${ }^{4}$ O PNLD é uma política pública executada pelo FNDE e pelo Ministério da Educação, destinado a avaliar e a disponibilizar obras didáticas, pedagógicas e literárias de forma sistemática, regular e gratuita, sendo um dos maiores programas de distribuição de livros do mundo. Disponível em: https://pnld.nees.com.br/pnld_2019/escolha. 